\title{
Peran Alergi Makanan dan Alergen Hirup pada Dermatitis Atopik
}

\author{
Sjawitri P Siregar
}

\begin{abstract}
Sensitisasi makanan dan aeroalergen memegang peran pada patogenesis penyakit atopik seperti dermatitis atopik (DA), rinitis alergik dan asma. Dermatitis atopik merupakan suatu penyakit kronik yang tidak dapat disembuhkan $100 \%$ dan sering mengalami eksaserbasi, serta menimbulkan masalah pada orang tua dan dokter. Banyak faktor yang berperan pada DA, baik faktor eksogen atau endogen maupun kombinasi keduanya. Faktor genetik merupakan salah satu faktor yang berperan pada DA. Faktor eksogen seperti makanan aeroalergen banyak dilaporkan sebagai pencetus timbulnya DA. Masih terdapat perbedaan pendapat mengenai makanan sebagai penyebab tetapi terdapat bukti bahwa bila makanan dihindarkan gejala dermatitis membaik. Susu sapi memprovokasi gejala DA pada usia bayi ${ }^{1}$ dan $30 \%$ DA disebabkan alergi susu sapi ${ }^{2}$.

Alergen hirup seperti tungau debu rumah berperan pada patogenesis DA, terutama pada anak; hal ini berdasarkan beberapa pengamatan klinis, uji kulit dan IgE spesifik yang tinggi serta terdapat perbaikan gejala klinis DA setelah penghindaran tungau debu rumah. ${ }^{3}$ Alergen makanan lebih berpengaruh pada usia bayi kurang dari 1 tahun sedangkan aeroalergen pada usia di atas 2 tahun. ${ }^{4} \mathrm{H}$ asil penelitian di Departemen IKA RSCM menunjukkan bahwa DA pada anak dengan onset kurang dari 1 tahun yang telah tersensitisasi telur dan aeroalergen akan meningkatkan risiko alergi saluran napas di kemudian hari sampai sepuluh kali lipat. ${ }^{5}$
\end{abstract}

Kata kunci: alergen makanan, alergen hirup, dermatitis atopik

$C^{2}$ sma, rinitis alergi dan dermatitis atopik mempunyai dasar kelainan respons $\mathrm{IgE}$ hipersensitivitas dan inflamasi jaringan spesifik yang ditandai dengan infiltrasi lokal sel limfosit $\mathrm{T}$ memori, sel eosinofil dan sel monosit/makrofag. Pada jaringan yang sedang mengalami inflamasi akut, akan tampak infiltrasi sel limfosit T dengan ekspresi IL-4, IL-5, dan IL-13. Sitokin ini diperkirakan memegang

Alamat korespondensi:

Dr. Sjawitri P. Siregar, Sp.A(K).

Divisi Alergi Imunologi. Departemen Ilmu Kesehatan Anak FKUI RSCM, Jakarta.

Jl. Salemba No. 6, Jakarta 10430.

Telepon 021-316 1144. Fax. 021-390 7743. peran utama pada respons alergi. Pada DA respons inflamasi yang terjadi lebih kompleks dan melibatkan bukan reaksi hipersensitivitas IgE saja, tetapi beberapa sel juga mengekspresikan IgE pada permukaannya seperti sel monosit / makrofag dan sel Langerhans.

Umumnya orang awam mengartikan alergi makanan untuk semua reaksi yang tidak diinginkan yang timbul akibat makanan (adverse food reaction). Sebenarnya alergi makanan yang dimaksud adalah yang diperantarai oleh imunoglobulin $\mathrm{E}$ ( $\mathrm{IgE})$, dan yang dapat menimbulkan reaksi dari yang ringan seperti urtikaria sampai yang berat yang dapat mengancam jiwa berupa reaksi anafilaksis, sehingga alergi makanan yang IgE mediated lebih banyak dipelajari dan dilaporkan. Asma, rinitis alergi dan dermatitis atopik mempunyai dasar kelainan respons IgE hipersensitivitas dan inflamasi 
jaringan spesifik yang ditandai dengan infiltrasi lokal sel T memori, sel eosinofil dan sel monosit/makrofag. Pada jaringan yang sedang mengalami inflamasi akut, akan tampak infiltrasi sel limfosit T dengan ekspresi IL4, IL-5, dan IL-13. Sitokin ini diperkirakan memegang peran utama pada respons alergi. Tetapi alergi makanan yang menimbulkan DA dapat juga diperantarai oleh cell mediated immunity ${ }^{6}$ Sedangkan alergi makanan yang diperankan oleh reaksi hipersenitivitas tipe II dan III jarang dilaporkan.

Sensitisasi alergen spesifik sangat dipengaruhi oleh faktor genetik walaupun faktor lingkungan berpengaruh untuk timbulnya penyakit alergi. Pada bayi baru lahir yang berasal dari keluarga atopi sampai usia 1 tahun respons interleukin-5 (IL-5) meningkat sedangkan respons interferon gamma (IFN- $\gamma$ ) dan interleukin -13 (IL-13) rendah. Penurunan kadar IFN- $\gamma$ dan IL-13 makin bertambah bila bayi telah disensitisasi oleh telur. Ditambah lagi terdapat bukti bahwa pada bayi baru lahir polarisasi keseimbangan lebih ke arah TH2 (peningkatan IL-5 dan IL-13) sehingga terdapat peningkatan sel eosinofil dan IgE pada umur 1 tahun. ${ }^{7}$ Banyak laporan yang membuktikkan bahwa seorang bayi yang mempunyai bakat atopik bila dirangsang alergen makanan di usia muda akan dapat tersensitisasi aeroalergen di kemudian hari pada usia setelah 2 tahun. ${ }^{8}$

Dalam perjalanan alamiah penyakit atopik yang dikenal sebagai allergic march, sensitisasi dengan alergen makanan pada usia bayi akan diikuti sensitisasi alergen hirup di kemudian hari. Jadi pada usia tahun pertama gejala DA dan alergi makanan akan diikuti oleh asma dan rinitis alergi di kemudian hari. Penelitian kohort di Jerman juga melaporkan bahwa adanya sensitisasi dengan telur pada usia < dari 12 bulan dapat digunakan sebagai dugaan akan terjadi sensitisasi dengan aeroalergen pada usia 3 tahun' Peran aeroalergen pada DA dilaporkan lebih banyak pada usia $>2$ tahun yang dibuktikan dengan uji tempel dan IgE spesifik dalam serum $^{4,10,11,12}$

\section{Peran alergen makanan pada dermatitis atopik}

Masih ada beda pendapat mengenai peran alergen makanan pada DA. Laporan hasil penelitian menunjukkan bahwa prevalensi alergi makanan pada DA juga berbeda. Ahli penyakit kulit dari Amerika Serikat berpendapat bahwa hanya sebagian kecil peran alergen makanan pada DA dan Hanifin ${ }^{13}$ pun melaporkan hanya $10 \%$ alergen makanan berperan pada DA. Sedangkan Sampson ${ }^{14,15}$ mendapatkan angka lebih tinggi yaitu 74\% dan 65\%. Dari Singapore dilaporkan bahwa alergen makanan berperan pada 10\% DA ringan dan $37 \%$ pada DA yang sedang. ${ }^{16,17}$

Menegakkan diagnosis alergi makanan sukar karena sering terdapat kadar IgE spesifik makanan dalam serum meninggi tetapi tidak sesuai dengan gejala klinis dermatitis, sehingga uji eliminasi dan provokasi makanan harus dilakukan untuk menegakkan diagnosis pasti. Peran alergen makanan terutama susu sapi pada bayi yang menderita dermatitis atopi telah jelas; 30\%$50 \%$ DA disertai dengan alergi susu sapi ${ }^{1,2,10}$

\section{Beberapa jenis makanan yang dapat menimbulkan alergi}

Semua makanan dapat menimbulkan reaksi alergi, namun beberapa makanan lebih bersifat alergenik dari makanan yang lain.

1) Golongan makanan yang paling sering menimbulkan alergi yaitu susu sapi, susu kambing, telur, kacangkacangan, ikan laut, kacang kedele serta gandum

a) Susu sapi mengandung kurang lebih 20 macam komponen protein yang masing-masing dapat merangsang pembentukan antibodi IgG, IgA, IgM dan IgE. Pada pasien atopi kadar IgE total dan IgE spesifik makanan akan lebih tinggi dari anak-normal. Fraksi protein susu sapi terdiri dari protein whey dan casein. Beberapa protein whey dapat didenaturasi dengan proses pemanasan ( hidrolisis). Terdapat dua macam susu sapi yang telah dihidrolisis yaitu yang sebagian (partially denaturated cow's milk) dan denaturasi yang lengkap (extensive denaturated cow's milk). Terdapat reaksi silang antara susu sapi dan susu kambing / domba. Telur ayam juga merupakan alergen yang sering menyebabkan gejala DA pada anak. Putih telur lebih bersifat alergenik dari kuning telur dan mempunyai 23 macam glikoprotein seperti ovalbumin, ovomukoid, dan ovo transferin ${ }^{18}$ Terdapat reaksi silang antara putih telur dan protein telur unggas yang lain. ${ }^{19}$ Bila telah tersensitisasi dengan alergen telur pada usia 12 bulan maka dapat diduga akan alergi terhadap alergen hirup di kemudian hari.' 
b) Kacang-kacangan seperti kacang tanah, kacang mede, dan sejenisnya dapat menyebabkan reaksi alergi makanan. Di Amerika Serikat alergi kacang lebih sering didapat dan sering menimbulkan reaksi anafilaksis, tetapi tidak demikian di negara Asia (Singapore, Thailand, Filipina, Cina dan Indonesia). ${ }^{21}$ Protein kacang terdiri dari albumin yang larut dalam air dan globulin yang tidak larut dalam air yang terdiri dari fraksi arachin dan conarchin

c) Ikan laut sering menimbulkan alergi makanan dengan manifestasi di kulit dan saluran napas seperti urtikaria, angioedema dan asma. Dengan proses pemasakan sebagian besar alergen utama dalam ikan laut dapat dihancurkan.

d) Kacang kedele banyak dilaporkan menimbulkan alergi makanan di negara Barat, tetapi jarang dilaporkan di Indonesia. Susu kacang kedele digunakan sebagai pengganti susu sapi pada bayi yang alergi susu sapi. Gandum yang banyak terdapat dalam tepung dapat juga menimbulkan alergi makanan

2) Makanan lain yang dapat menimbulkan alergi makanan adalah coklat, tomat dan bahan aditif seperti zat penyedap (monosodium glutamate), zat pengawet ( asam benzoat, salisilat, sulfit) dan zat warna (tartrazin) dapat juga menyebabkan reaksi alergi makanan palsu.

Prevalensi alergi makanan paling tinggi pada usia tahun pertama kehidupan, yaitu sekitar $6 \%$ untuk usia di bawah 3 tahun sedangkan untuk bayi sekitar 10-12\% ${ }^{13,14}$. Prevalensi alergi makanan terdapat pada $40 \%$ kasus DA. ${ }^{22,23}$ Anak dengan penyakit atopik akan mempunyai alergi makanan lebih tinggi dari anak normal.

\section{Peran alergen hirup pada dermatitis atopik}

Alergen hirup dibagi atas aeroalergen dalam rumah dan di luar rumah. Kedua aeroalergen tersebut banyak terdapat di kamar tidur terutama di kasur, bantal, selimut bulu, karpet bulu, mainan anak yang berbulu dan gorden. Di daerah tropis seperti di Indonesia lebih berpengaruh aeroalergen dalam rumah yang sebagian besar disebabkan oleh Dermatophagoides pteronyssinu, Dermatophagoides farinae, dan debu rumah.

Alergen lain seperti Candida albicans, kecoa, serpihan kulit binatang piaraan kucing, anjing, kelinci dan burung. Di Singapore selain alergen di atas dilaporkan juga Blomia tropicalis yang banyak terdapat sebagai aeroalergen dalam rumah. ${ }^{21}$

Telah diketahui pada alergic march, DA akan mendahului timbulnya asma di kemudian hari dan diamati bahwa anak dengan DA dan uji kulit positip dengan $D$. pterenosynnus akan mendapat asma berat dibandingkan dengan anak tanpa DA. Apakah anak dengan DA tersensitisasi dengan aeroalergen atau aeroalergen menyebabkan DA bersamaan dengan provokasi saluran napas? Didapat hasil uji tempel dengan $D$. pteronisynus positip pada $34 \%$ pasien DA usia 2-10 tahun. Pada usia $<2$ tahun sensitisasi alergen makanan lebih sering, sedangkan aeroalergen dan makanan pada usia 2-10 tahun sedangkan pada usia $>10$ tahun lebih sering oleh aeroalergen. ${ }^{4}$ Pada anak usia 5-14 tahun di Jerman dilaporkan hubungan yang signifikan antara beratnya skor eksem dengan konsentrasi IgE spesifik tungau debu rumah dan serpihan bulu kucing. ${ }^{24}$ Uji kulit dengan aeroalergen lebih sering positip (2 kali lipat) pada usia 24 bulan daripada usia 12 bulan sedangkan sensitisasi dengan makanan berkurang dengan bertambahnya umur. ${ }^{25}$ Penelitian menunjukkan bahwa penyuntikan protein antigen pada kulit tikus akan menimbulkan gejala lokal DA dan hiperresponsif bronkus. ${ }^{11}$ Dapat disimpulkan bahwa sensitisasi alergen melalui kulit akan meninggikan respons sistemik yang kemudian akan berdampak pada saluran napas.

Peran aeroalergen pada DA dilaporkan lebih banyak pada usia $>2$ tahun yang dibuktikan dengan uji tempel dan IgE spesifik dalam serum ${ }^{4,10,11,12} \mathrm{Di}$ Poliklinik Alergi Imunologi IKA RSCM, DA pada usia $<1$ tahun dan disertai alergen hirup dan sensitisasi telur usia $<1$ tahun akan meningkatkan risiko seorang anak mendapat alergi saluran napas di kemudian hari sampai 10 kali. $^{5}$

\section{Kesimpulan}

Sensitisasi alergen makanan dan aeroalergen memegang peran penting pada etiopatogenesis dermatitis atopik. Alergen makanan lebih berpengaruh pada usia kurang dari 1 tahun sedangkan aeroalergen pada usia di atas 2 tahun. Bila seorang bayi telah menderita DA, sebaiknya dihindarkan juga dari aeroalergen seperti debu rumah, tungau debu rumah, serpihan binatang piaraan burung, kucing, anjing dan kelinci dihindarkan sejak 
dini, karena dermatitis atopik dengan onset dini dan disertai sensitisasi aeroalergen serta telur akan meningkatkan risiko alergi saluran napas di kemudian hari. Terdapat bukti bahwa rangsangan faktor lingkungan pada sistem imun pada usia dini akan menyebabkan respons polarisasi ke arah Th2.

\section{Daftar Pustaka}

1. Hattevig G, Kjellman B, Bjorksten B, Johansson SGO. Clinical symptoms and IgE responses to common food proteins in atopic and healthy children. Clin Allergy 1984; 14:551-7.

2. Lebenthal F. Cow's milk protein allergy. Pediatr Clin North Am 1975; 22:827-33.

3. Chapman RD, Rountrees S, Mitchell EB. Quantitative assessment of IgG and IgE antibodies to inhalants allergen in patients with atopic dermatitis. J Allergy Clin Immunol 1983; 72:27-31.

4. Escarrer JM,Munoz-LopezF. Role of aeroallergens in the etiopathogenesis of atopic dermatitis. Allergol Immunolpathol, 2002; 30:126-34.

5. Sjawitri P Siregar, Bambang Madiyono, Amar W Adisasmito. Risk factors of respiratory allergy in children with atopic dermatitis. Paediatr Indones 1999; 39:134-44.

6. Kondo N, Fukutomi O, Agata H. The role of T lymphocytes in patients with food sensitive atopic dermatitis. J Allergy Clin Immunol 1993; 91:658-68.

7. Neaville WA, Tisler C, Bhattacharya A, Anklam K, Gilberston-White S, Hamilton R, dkk. Developmental cytokine response profiles and the clinical and immunologic expression of atopy during the first year of life. J Allergy Clin Immunol 2003; 112:740-6.

8. Van Asperen PP, Kemp AS. The natural history of IgE sensitization and atoipic disease in early childhood. Acta Paediatr Scand 1989; 78:239-45.

9. Nickel R, Kulig M, Foster J. Sensitisation to hen's egg at age of twelve months is predictive for allergenic sensitization to common indoor and outdoor allergens at the age of three years. J Allergy Clin Immunol 1997; 99:613-7.

10. Vasar M, Julge K, Bjoksto B. Development of atopic sensitization and allergic diseases in early childhood. Acta Paediatr 2000; 89:523-7.

11. Beck LA, Leung DY. Allergen sensitization through the skin induces systemic allergic responses. J Allergy Clin Immunol 2000; 106:S258-63.
12. Albert JO, Marjolein $S$ de Bruin-Weller, Ingrid T,Zana TP, Rob CA, Jan GR de Monchy, dkk. Effect of mattress encasings on atopic dermatitis outcome measures in a double-blind, placebo-controlled study : The Dutch mite avoidance study. J Allergy Clin Immunol 2002; 110:500-6.

13. Hanifin JM. Atopic dermatitis. JK Allergy Clin Immunol 1984; 73:211-26.

14. Sampson HA.Food sensitivity and the pathogenesis of atopic dermatitis. JR Soc Med 1997; 90:2-8.

15. Hill DJ, Sporik R, Thornburn J, Hosking CS. The association of atopic dermatitis in infancy with immunoglobulin E food sensitization. J Pediatr 2000; 137:475-9.

16. Hanifin JM. Atopic dermatitis in infants and children. Pediatr Clin North Am, 1991; 38:763-89.

17. Eigenmann PA, Sicherer SH, Borkowski TA, Cohen BA, Sampson HA. Prevalence of IgE mediated food allergy among children with atopic dermatitis. J Pediatrs, 1987; 463-4.

18. Hoffman DR. Immunochemical identification of allergens in egg white. J Allergy Clin Immunol 1983; 71:481-6.

19. Langland T: A clinical and immunological study of allergy to hen's egg white. Occurance of proteins crossreactivity with allergens in hen's egg white as studied in egg white from turkey, duck, goose, seagull and in hen's egg yolk, and hen and chicken sera and flesh. Allergy, 1983; 38:399-412.

20. Lee Bee Wah. Food and aeroallergen in atopy. $3^{\text {rd }}$ Regional scientific meeting on Paediatric Dermatollogy; Singapura; November 1999.

21. Eigenmann P, Siecherer S, Borowski T, Cohen B, Sampson HA. Prevalence of IgE-mediated food allergy among children with atopic dermatoitis. Pediatrics 1998; 101:8-13.

22. Niggemann B, Sielaff B, beyer K, Binder C, Wahn U. Outcome of double-blind, placebo-controlled food challenge test in 107 children with atopic dermatitis. Clin Exp Allergy, 1999; 29:91-6.

23. Julge K, Vasar M, Bjorksten B. Development of allergy and $\operatorname{IgE}$ antibodies during the first five years of life in Estonian children. Clin Exp Allergy 2001; 31:1854-61.

24. Schafer T, Heinrich J, Wjst M, Ring J, Wichmann HE. Association between severity of atopic eczema and degree of sensitization to aeroallergens in schoolchildren. J Allergy Clin Immunol 1999; 104:1280-4.

25. Oranye AP, Wolkersytorfer A, de Waard-van der Spek FB. Natural course of cow's milk allergy in childhood atopic eczema/dermatitis syndrome. Ann Allergy Asthma Immunol 2002; 89:52-5. 